Online ISSN:2583-0376
http://jpps.ukaazpublications.com
DOI: http://dx.doi.org/10.54085/jpps.2021.1.4.1
Journal of Phytonanotechnology and Pharmaceutical Sciences

Review Article : Open Access

\title{
Prospective of family Fabaceae (Angiosperms) in green synthesis: An indication
}

\author{
Bhawana Sharma, Raj Shreya, Medha Jha, and Afroz Alam*
}

Department of Bioscience and Biotechnology, Banasthali Vidyapith, Banasthali-304022, Rajasthan, India

\begin{tabular}{|c|c|}
\hline Article Info & Abstract \\
\hline $\begin{array}{l}\text { Article history } \\
\text { Received } 3 \text { October } 2021 \\
\text { Revised } 6 \text { November } 2021 \\
\text { Accepted } 11 \text { November } 2021 \\
\text { Published Online } 30 \text { December } 2021\end{array}$ & $\begin{array}{l}\text { In current scenario, nanotechnology is an area of great interest for most of the researchers globally. } \\
\text { Nanotechnology dealing in nano sized particles (NPs) partaking a size of } 1-100 \mathrm{~nm} \text {. These NPs are of } \\
\text { immense potential in the fields of atomic physics, medicinal chemistry and pharmaceuticals along with } \\
\text { their relevance in some other fields. Due to congenial methodology, time saving and eco-friendly nature, } \\
\text { this approach is one of the most emerging strategies in biological science with multidimensional utility. }\end{array}$ \\
\hline $\begin{array}{l}\text { Keywords } \\
\text { Angiosperms } \\
\text { Fabaceae } \\
\text { Green synthesis } \\
\text { Nanotechnology }\end{array}$ & $\begin{array}{l}\text { Considering this, the present review study has been done to highlight the potential of the second largest } \\
\text { family of angiosperms (dicotyledons) Fabaceae. The family Fabaceae is well distributed in India and } \\
\text { aboard and hugely diversified. Apart from that numerous species, this family have been found to have } \\
\text { medicinal importance based on ethnobotanical claims and recent findings. Thus, this review will provide } \\
\text { a base work for the usefulness of many unexplored species of this family to be used in the green synthesis. }\end{array}$ \\
\hline
\end{tabular}

\section{Introduction}

Enquiry and examination of nanoparticles (NPs) synthesis for their possible biological actions have been expanded many folds in the last two decades. The frequent agents of choice for the synthesis of NPs are mostly carbon and metal ions such as silver and gold (Brunner et al., 2006). The arena of nanotechnology is one of the most worked areas of modern research related to field of material science. NPs exhibit entirely novel or upgraded properties in contrast to their optimal sized counterparts. Due to congenial methodology, time saving, and eco-friendly nature NPs are one of the most emerging strategies in biological science due to its multidimensional utility (Natesh and Mohan, 1999). The metal-based NPs have a high specific surface area and a high fraction of surface atoms. These particles also have exclusive physicochemical features, viz., optical properties, catalytic activity, electronic properties, magnetic properties and antibacterial properties (Gonzales-Melendi et al., 2008). With time the NPs are getting more and more attentions with every exploration by the scientific community working in this field.

Consequently, several procedures have been established for the synthesis of metal-based NPs. Now, synthesis of NPs is being done using several methods including physical, chemical and biological systems. Every method has its advantages and drawbacks, for instance, the most popular chemical method needs less time for synthesis of large number of NPs and necessitates capping agents for size maintenance of the NPs. But usually, the synthesis and stabilization processes of NPs are commonly toxic and lead to hazardous byproducts. Hence, there is a need to develop eco-friendly protocols to generate NPs, at this point the concept of green synthesis arises which leads to the emerging attention in biological

\section{Corresponding author: Dr. Afroz Alam}

Associate Professor, Department of Bioscience and Biotechnology, Banasthali Vidyapith, Banasthali-304022, Rajasthan, India E-mail: afrozalamsafvi@gmail.com

Tel.: +91-9415596994

Copyright () 2021 Ukaaz Publications. All rights reserved.

Email: ukaaz@yahoo.com; Website: www.ukaazpublications.com methods to restrict the impact of hazardous pollutants (byproducts) in the environment. Subsequently, the demand of green synthesis (green technology) has increased (Handy et al., 2008a, b) and in recent past numerous biotic tactics for both intracellular and extracellular NPs production have been reported using bacteria, fungi, algae and land plants (Harris and Bali, 2008).

In case of land plants usually angiosperms are the preferred choice (Ball, 2002; Alam and Sharma, 2012; Alam et al., 2019; 2021). Several families are of interest for their utility in green synthesis. Among angiosperms invariable the families of wildly growing plants have been targeted for such purposes. Families, such as Asteraceae, Fabaceae, Amaranthaceae, etc., are suitable candidates for synthesis of nano-particles as not only these families are diversified, easily available but also have huge medical properties and are being used in traditional medicinal systems. In this review, the specific focus is on the family Fabaceae.

\section{Family Fabaceae}

Fabaceae family, previously known as Leguminosae is the thirdlargest family after Orchidaceae and Asteraceae with 730 genera and about 19,400 species. The largest genera are: Indigofera $(>700$ species), Astragalus (>3000 species), Mimosa (> 300 species), Acacia (>1000 species), Crotalaria (>700 species) which contain around $9.4 \%$ of all flowering plant species (Mishra, 2015). This family of angiosperms comes second just after Poaceae in terms of economic gains (Borges et al., 2013). It includes annual or perennials shrubs, trees, and herbaceous plants that are easily recognized by their compound, stipulated leaves, and their fruits (legumes) (Bharti and Sharma, 2009). The Fabaceae family is widely distributed particularly in North America, Europe, Asia, and cold mountainous regions. It is also abundant in Central Asia and has a significant economic impact (Hossain et al., 2012; Al-Joboury, 2021). This large family was originated 60 million years ago and currently subdivided into three subfamilies: Cesalpinodeae (2250 species), Pappilionoideae (13800 species), and Mimisoideae (3270 species). 
The species of this family have huge ecological significance as most of them able to fix atmospheric nitrogen through symbiosis, viz., soybean, chickpea, and peanut which account for $20 \%$ all crops (Zheng et al., 2016).

\subsection{Ethnobotany}

Due to lesser side effects, herbal formulations are gaining escalating faith and wild plants are still explored by the villagers for ethnomedicinal purposes. Ethnobotany seems to be a relatively recent branch of study, on condition that herbs are studied carefully properly and methodically in this subject, anthropologists, linguistics, archeologists, plant geographer, ethno-botanist botanists, and phytochemists will be able to produce results of significant value (Kumar et al., 2014).

Ethnobotanical studies are important to understand how these plants are used for medical purposes by traditional communities as well as to preserve folk culture (Table 1). The findings of ethnobotany investigations help to contributes to the association between modern and traditional knowledge, being a vital tool for studying the biological features of medicinal plants (Macedo et al., 2020). Omondi and Omondi (2015) studied that Fabaceae family plant species show antioxidant and antimicrobial properties which were utilized at the industrial level. Mehra and De (2017) reported plants of the
Fabaceae family to have significant contents of alkaloids, tannins, steroids, terpenoids, etc., which exhibit greater antioxidant activity that can be linked to the prevention of degenerative diseases such as cancer, neurological illness, and cardiovascular diseases. They also reported that the plants of the Fabaceae family inhibit natural antioxidant compound which is bioactive and can be utilized as dietary supplements in the food industry (Mehra and De, 2017).

\subsection{Medicinal properties of Fabaceae family}

Phytochemicals found in this family are categorized into two groups: primary or secondary. The primary components of phytochemical comprise sugars, amino acids, protein, and chlorophyll. The secondary components consist of terpenoids, saponins, flavonoids, and tannins. Many of these have been studied and are still being studied under natural products chemistry and phytochemistry (Shakeri et al., 2012). Phenolics acids, flavonoids, triterpenes, aldehydes, and lipids have been found in the plants and seeds of legumes. It synthesizes these compounds and reserves them in a significant concentration of the vacuoles (in the case of hydrophilic compounds), resin ducts, and cuticles (Wink, 2013). These phytochemicals include a chemical complex with nitrogen that comprises amines and alkaloids (imidazole alkaloids, cyanogenic glucosides, phenylethylamine, and tryptamine derivatives.

Table 1: Some of the frequently used and widely plants of family Fabaceae for curative purpose (Alam and Sharma, 2012)

\begin{tabular}{|c|c|c|c|}
\hline S. No & Botanical name and habit & Local name & Plant part used/medicinal uses \\
\hline 1. & $\begin{array}{l}\text { Vachellia nilotica (L.) P.J.H.H urter \& Mabb } \\
\text { (Acacia Arabica) (Tree) }\end{array}$ & Babool & $\begin{array}{l}\text { Gum, stem, branches used to treat leucorrhoea and } \\
\text { bronchitis }\end{array}$ \\
\hline 2. & Cassia fistula L. (Tree) & Amaltas & Seed and fruit pulp used to cure diarrhea, malaria \\
\hline 3. & Tamarindus indica $\mathrm{L}$. (Tree) & Imli & $\begin{array}{l}\text { Leaves and fruits used to cure from intestinal worms } \\
\text { and to stop dysentery }\end{array}$ \\
\hline 4. & Abrus precatorius L. (Shrub) & Ghunchu & $\begin{array}{l}\text { Leaves, roots, fruits and seeds are variously used to } \\
\text { treat fever, pain, leukoderma, bronchopneumonia, } \\
\text { and as birth control pills }\end{array}$ \\
\hline 5 . & Bauhinia racemosa Lam. (Tree) & Maoli & Laves are used to promote normal urination \\
\hline 6. & $\begin{array}{l}\text { Millettia pinnata }(\text { L.) Panigrahi } \\
\text { (Pongamia pinnata) }(\text { Small Tree) }\end{array}$ & Karanja & Seeds are used to treat arthritis and skin itching \\
\hline 7. & Saraca indica L. (Tree) & Ashoka & Bark is used in treatment of cystitis \\
\hline 8. & Butea monosperma (Lam.) Taub. (Tree) & Palas, Dhak & $\begin{array}{l}\text { Flower, stem and wood used to treat worm ring, } \\
\text { eczema, snakebite and to improve menstrual cycle }\end{array}$ \\
\hline 9. & Mucuna pruriens (L.) DC. (Herb) & Kiwanch & $\begin{array}{l}\text { Fruits and seeds are used to improve sexual vigor, } \\
\text { to remove weakness, dizziness, and to treat cholera }\end{array}$ \\
\hline 10. & Uraria picta (Jacq.) Desv. ex DC (Shrub) (Herb) & Pithwan & $\begin{array}{l}\text { Leaves are used as an antidote to snake bites and to } \\
\text { treat piles }\end{array}$ \\
\hline
\end{tabular}

\subsection{Phytochemistry}

Phytochemicals are a large group of chemicals that are not essential for growth but important in providing flavors, aromas, and toxins against the predators (Barbieri et al., 2017). Legumes have several sources of these phytochemicals which have traditionally been used as poisons and are used currently in the pharmaceutical industry (Birben et al., 2012). They have reactive oxygen species (ROS) that are highly active species that damage DNA, lipids, proteins, and carbohydrates in the cell. Members of this family Fabaceae have evolved a large family of antioxidants defenses like polyphenols which can suppress the ROS. There are around 19,400 species in the legume family (Fabaceae). Some of these species such as Cicer arietinum, Phaseolus vulgaris and Cajanus cajan contain important nutritional components, providing protein to over 300 million people across the world. Likewise, soybean (Glycine max) and peanut (Arachis hypogaea) produce and over $35 \%$ of the world's refined vegetable oil, soybean, and peanut are also good sources of nutritional protein for the hog and poultry industries (Graham and Vance, 2003). It has also been reported that the plant of this family is a boon for effective and safe medicine due to the lack of essential oils. The plants belonging to the Fabaceae 
family are found to have different phytochemical which has varied activities. Pulses are considered beneficial nontoxic grains that provide both food supplements and a wide range of medicinal applications.

\section{Antioxidant properties}

The natural antioxidants mainly consist of polyphenols like phenolic acids and flavonoids and carotenoids like carotenes and vitamins like vitamin $\mathrm{E}$ and vitamin $\mathrm{C}$ are found in the members of this family. There is a lot of interest in these antioxidants as they have medicinal uses for major diseases like cancer and cardiovascular diseases. These phenolic compounds have an aromatic ring with hydroxyl groups. Along with phenolic acids, there are high molecular weight compounds called tannins which also have phenolic groups. Along with these flavonoids, which are chemically glycosides and aglycones (Kapoor, 2015).

\section{Bioactive constituents}

Natural antioxidants found in seeds and leaves of the members of this family, such as, vitamin E, ascorbic acid, and phenolic compounds have been shown in order to avoid the oxidative damage associated with many diseases such as diabetes, cataracts, cardiovascular diseases, cancer, atherosclerosis, arthritis, and ageing (Tariq et al., 2017).

\subsection{Phenols}

The species of this family have diverse capacities to synthesize secondary metabolites, the majority of which are phenolic. More than 12000 secondary metabolites have been isolated from the medicinal plants but only around $10 \%$ of the total secondary metabolites belongs to phenolic classes (Schulte et al., 1990). Phenolics are a diverse class of physiologically active plant components. Various phenolic compounds including stilbenes, phenolic acids, lignins, coumarins, and tannins are abundant in various parts of medicinal plants (Borkataky et al., 2013). The presences of phenolic compounds in plants are responsible for several biological effects including antimicrobial, antioxidant, antiinflammatory, antihypertensive, and antimutagenic properties as well as the potential to alter the expression of the gene (John et al., 2014). Due to their significant antioxidant activities, they are also known as radical scavengers, singlet oxygen quenchers, reducing agents, and metal chelators the species of this family are good candidates for the synthesis of NPs (Handy et al., 2008a; Sahu and Saxena, 2013).

\subsection{Flavonoids}

Another major class of secondary compounds is flavonoids, a group of polyphenolic compounds, widely distributed and commonly found in this family (Tapas et al., 2008). Flavonoids are glycosides that are present in leaves, stems, leaves, flowers, and bark of many species of Fabaceae (Rajeshwar et al., 2005; Mohammed et al., 2013). Flavonoids have been shown to have antiulcer, antiallergic, antiarthritic, anti-inflammatory, anticancer, antiarthritic, antithrombotic, protein kinase inhibition, and mitochondrial adhesion, etc. (Sebastian et al., 2020). Furthermore, they protect against cardiovascular diseases and are also known to have hepatoprotective properties (Tyler et al., 1988; Ozyurt et al., 2004). Because they have a wide spectrum of pharmacological actions in the human body, these are also known as nutraceuticals as NPs (Kumar et al., 2013).

\subsection{Alkaloids}

Plant derived alkaloids are often used in medicine and recreational drugs because of their pharmacological effects (Jain et al., 2019). They also act as defense response in plants. Because of their potent biological activity, several alkaloids have also been used as narcotics, stimulants, pharmaceuticals, and poisons because of their strong biological activities. The plant-derived alkaloids currently used in clinical practice that include the stimulant caffeine and nicotine, analgesic morphine, the antimalarial quinine sedative scopolamine, the anesthetic cocaine, the anticancer vinblastine, etc. These are also used as disinfectants in medicine (Shahidi et al., 1992; Shamsa et al., 2008). Gnanaraja et al. (2014) have studied the anticancerous, antimicrobial, antidiuretic, antidiabetic, and anti-inflammation activities of the secondary metabolites extracted from the Fabaceae family. The secondary metabolites like pyrrolizidine alkaloids are often found in plant extract of the Fabaceae family which exhibit different kinds of biological activities that include antitumoral, antiviral, hepatotoxic, and neuroactive properties (Gnanaraja et al., 2014). These plant extracts were used in ancient medicines for the prevention of leprosy, diarrhea, scabies, and fever (Aissaoui et al., 2014). Preliminary studies revealed the usefulness of Fabaceae species as a food resource and therapeutic level (Molares and Ladio, 2012).

\section{Use of phytochemicals in cancer therapy}

Various plant products including saponins, minerals, vitamins, glycosides, oils, gums, biomolecules, alkaloids, flavonoids, lignans, terpenes, and other primary and secondary metabolites play an important role in either inhibiting cancer cell-activating enzymes, proteins or by activating the mechanism of DNA repair and inducing antioxidant action. As a result of their effectiveness on the proteins, enzymes, and signaling pathways, these phytochemicals have significant anticancer effects (Thakore et al., 2012; Srikanth and Chen, 2016). The NPs produced with these plant extracts have shown the increase in effectiveness in cancer therapy (Geethika $e t$ al., 2018)

\section{Pharmacological activities}

The phytochemistry of the various species of Fabaceae confirmed that they have different pharmacological actions and are being used in anticancer therapies, it is expected that with the combination of nanotechnology the anticancer potential will increase many folds with accurate targeting of cancerous cells. Combinatorial chemistry, isolation tests, and bioassay-guided fractionation are some of the methods used to purify active phytochemicals (Amin and Barkatullah, 2016). For this, the active extracts can be subsequently fractionated using suitable matrices and bioactivity is assessed using a range of analytical methods such as FTIR, HPLC, NMR, FTIR, and Mass spectroscopy, etc. (Ocho-aninatchibri et al., 2010; Dar et al., 2017).

\section{Discussion}

The analysis of the health facilities and plants as therapeutic agents is important not only for addressing traditional societies' medical issues but also with the knowledge of NPs synthesis can be of great use in modern medication. The wealth of family Fabaceae as healing herbs suggests a significant opportunity for the study and development of novel medicines to combat diseases like diabetes, cardiovascular diseases, etc., in association with the nanotechnology 
by synthesizing useful NPs. The family Fabaceae is a natural reservoir of important phytochemicals and antioxidants which have both medicinal and industrial uses (Ahmad et al., 2016; Mac Alister et $a l ., 2018$ ). Efforts are presently being undertaken to use the wealth of phytochemical from this family in green synthesis; however, very few species have been used for the synthesis of NPs and most of species are almost untouched (Aung et al., 2017). Therefore, this necessitates the synergistic efforts from plant taxonomists, phytochemists and nanotechnologists to devote their efforts on various aspects of these plants in green synthesis.

\section{Conclusion}

In recent past, amazing advancement has been occurred in the development of nanotechnology. Furthermore, the expansion of nanotechnology has guided the speedy progress of profitable application which engages the utilization of a huge assortment of man-made NSPs. The employ of these organic and inorganic nanosized resources may upshot in the liberation of these noxious materials into the surroundings where the main environmental acceptors of these byproducts will be soil, sediment and biosolids from wastewater management. In such cases, green synthesis is of great importance in contemporary demand of eco-friendly approaches for healthcare and nutraceutical sectors. Plants have always been natural resources of medication with almost negligible release of hazardous byproducts. In nanotechnology, the restriction of these byproducts is a big issue that can be well addressed by the use of plant derived byproducts which are immensely important for the green synthesis. In this drive, several wildly growing members of family Fabaceae would be of great use and should be used more extensively as they are not only an aid to NPs synthesis but also a hoard of bioactive compounds. Till date, some of the members have been evaluated and used in this direction still a huge diversity of this family waiting to help the mankind.

\section{Acknowledgments}

The author would like to express her gratitude to Professor Ina Aditya Shastri, Vice-Chancellor, Banasthali Vidyapith, Rajasthan for her support and encouragement. We are also grateful to DST for providing networking support through the FIST program at the Department of Bioscience and Biotechnology, Banasthali as well as the DBT funded Bioinformatics Center, Banasthali Vidyapith, Rajasthan, India.

\section{Conflict of Interest}

The authors declare no conflicts of interest relevant to this article.

\section{References}

Ahmad, F.; Anwar, F. and Hira, S. (2016). Review on medicinal importance of Fabaceae family. Pharmacology Online, 3:151-156.

Aissaoui, M.; Leon, F.; Brouard, I.; Benayache, F. and Benayache, S. (2014) Secondary metabolites from Crotalaria saharae (Fabaceae). Der Pharm. Lett., 6(1):186-189.

Alam, A. and Sharma, V. (2012). Textbook of Economic Botany. Pointer Publishers, India, pp:317.

Alam, A.; Kanchan and Iwuala, E. (2019). Contemporary medicinal uses of ethnomedicinally important plant [Terminalia arjuna (Roxb) Wight and Arn.]. Ann. Phytomed., 8(1):63-69.
Alam, A.; Baliyan, P.; Sharma, V. and Mazhar-ul-Islam (2021). Potential of bryophytes in nanotechnology: An overview. J. Phytonanotech. Pharmaceut. Sci., 1(1):1-3. http://dx.doi.org/10.21276/Citation jpps.2021.1.1.1

Al-Joboury, K.R. (2021). Review with checklist of Fabaceae in the herbarium of Iraq natural history museum. GSC Biol. Pharm. Sci., 14(3):137142 .

Amin, S. and Barkatullah, H.K. (2016). Pharmacology of Xanthium species: A review. J. phytopharm., 5:126-127.

Atchibri,A. L. O.; Kouakou, T.H.; Brou, K.D.; Kouadio,Y.J. and Gnakri, D. (2010). Evaluation of bioactive components in seeds of Phaseolus vulgaris L. (Fabaceae) cultivated in Côte d'Ivoire. J. Appl. Biosci., 31:19281934.

Aung, T.N.; Qu, Z.; Kortschak, R.D. and Adelson, D.L. (2017). Understanding the effectiveness of natural compound mixtures in cancer through their molecular mode of action. Int. J. Mol. Sci., 18(3):656.

Ball, P. (2002). Natural strategies for the molecular engineer. Nanotechnology, 13:15-28.

Barbieri, R.; Coppo,E.; Marchese,A.; Daglia, M.; Sobarzo-Sanchez, E.; Nabavi, S.F. and Nabavi S.M. (2017). Phytochemicals for human disease: An update on plant-derived compounds antibacterial activity. Microbiol. Res., 196:44-68.

Bharti, K.A. and Sharma, B.L. (2009). Studies on ethnoveterinary uses of plant resources of Sikkim. Indian For., 135(5):691.

Birben, E.; Sahiner, U.M.; Sackesen, C. Erzurum and Kalayci, O. (2012). Oxidative stress and antioxidant defense. World Allergy Organ J., 5(1):9-19.

Borges, L.; Bruneau, A.; Cardoso, D.; Crisp, M.; Delagado-Salinas, A.; Doyle, J.J. and Egan A. (2013). Towards a new classification system for legumes: Progress report from the $6^{\text {th }}$ International Legume Conference. S. Afr. J. Bot., 89:3-19.

Borkataky, M.; Kakoty, B.B. and Saikia, L.R. (2013). Influence of total phenolic content and total flavonoid content on the DPPH radical scavenging activity of Eclipta alba (L.) Hassk. Int. J. Pharm. Pharm., 5(1):224327.

Brunner, T. I.; Wick, P.; Manser, P.; Spohn, P.; Grass, R.N.; Limbach, L.K.; Bruinink, A. and Stark, W. J. (2006). In vitro cytotoxicity of oxide nanoparticles: Comparison to asbestos, silica, and effect of particle solubility. Environ. Sci. Technol., 40:4374-4381.

Dar, R.A.; Shahnawaz, M. and Qazi P.H. (2017). General overview of medicinal plants: A review. J. phytopharm., 6(6):349-351.

Geethika, B.; Sathak Sameer, S.M.; Ansel Vishal, L. and Thangavelu, L. (2018). Green synthesis of silver nanoparticles from heartwood extracts: Family of Fabaceae. Drug Invent. Today., 10:1-4.

Gnanaraja, R.; Prakash, V.; Shanta, P. and Mahendraverman, M. (2014). Qualitative and quantitative phytochemicals analysis of selected Fabaceae medicinal plants from Allahabad region. J. Pharm. Innov., 3(7):5356 .

Gonzales-Melendi, P.; Fernandez-Pacheco, R.; Coro-nado, M.J.; Corredor, E.; Testillano, P.S.; Risueno, M.C.; Marquina, C.; Ibarra, M.R.; Rubiales, D. and Perez-de-Luque, A. (2008). Nanoparticles as smart treatment-delivery systems in plants: Assessment of dif-ferent techniques of microscopy for their visualization in plant tissues. Ann. Bot., 101:187-195.

Graham, P.H. and Vance, C.P. (2003). Legumes: Importance and constraints to greater use. Plant physiol., 131(3):872-877.

Handy, R.D.; Owen, R. and Valsami-Jones, E. (2008a). The ecotoxicology of nanoparticles and nanoma-terials: Current status, knowledge gaps, challenges and future needs. Ecotoxicology, 17:315-325. 
Handy, R.D.; VonDer Kammer, F.; Lead, J.R.; Has-sellov, M.; Owen, R. and Crane, M. (2008b). The ecotoxicology and chemistry of manufactured nano-particles. Ecotoxicology, 17:287-314.

Harris, A.T. and Bali, R. (2008). On the formation and extent of uptake of silver nanoparticles by live plants. J Nanopart Res., 10:691-695.

Hossain, M.K.; Hassan, M.M.; Parvin, M.N.; Hasan, M.M.; Islam, M.S. and Haque, M.A. (2012). Antimicrobial, cytotoxic and thrombolytic activity of Cassia senna leaves (family: Fabaceae). J. App. Pharm. Sci., 2(06): 186-190.

Jain, C.; Khatana, S. and Vijayvergia, R. (2019). Bioactivity of secondary metabolites of various plants: a review. Int. J. Pharm. Sci. Res., 10(2):494-498.

John, B.; Sulaiman, C.T.; George, S. and Reddy, V.R.K. (2014). Total phenolics and flavonoids in selected medicinal plants from Kerala. Int. J. Pharm. Pharm. Sci., 6(1):406-408.

Kapoor, S. (2015). Bioactives and therapeutic potential of legumes: A review. Int. J. Pharm. Biol. Sci., 5:65-74.

Kumar, N.; Jakhar, A.K. and Choyal, R. (2014). Traditional uses of some medicinal plants of Hamirpur district of Himachal Pradesh for the treatment of diabetes. Int. J. Adv. Res., 2:131-138.

Kumar, D.; Kiran, D.; Ritesh, V. and Abhishek K. (2013). To evaluation of total phenolics and flavonoids in different plants of Chhattisgarh. J. Pharmacogn. Phytochem., 2(4):116-118.

Mac Alister, D.; Muasya, A.M. and Chimphango, S.B.M. (2018). Linking roo traits to superior phosphorus uptake and utilization efficiency in three Fabales in the Core Cape Subregion, South Africa. Funct. Plant Biol., 45(7):760-770.

Macedo, N.S.; Silveira, Z.D.S.; Bezerra,A.H.; Da Costa, J.G.M.; Coutinho, H.D.M. Romano, B.; Capasso, R.; Da cunha, F.A.B. and Da Silva, M.V. (2020). Caesalpinia ferrea C. Mart. (Fabaceae) phytochemistry, ethnobotany and bioactivities: A review. Molecules, 25:3831.

Mehra, Y.K. and De, K. (2017). Determination of phytochemical, total flavonoids and antioxidant activity of methanolic extract of Pisum sativum. Int. J. Inno. Pharm. Sci. Res., 5(8):1-12.

Mishra, A. (2015). Study on some ethnomedicinal plants of Kalinjar hillock, Banda district (U.P.) India. Int. J. Adv. Res. Eng. Appl. Sci., 4(7):1-9.

Mohammed, H.A.; Alshalmani, S.K. and Abdellatif, A.G. (2013). Antioxidan and quantitative estimation of phenolics and flavonoids of three halophytic plants growing in Libya. J. pharmacogn. phytochem., 2(3):89-94

Molares, S. and Ladio, A. (2012). The usefulness of edible and medicinal Fabaceae in Argentine and Chilean Patagonia: Environmental availability and other sources of supply. Evid. Based Complement Alternat. Med., 2012:901918.

Natesh, S. and Mohan Ram, H.Y. (1999). An update on green medicine. J. Indian Bot. Soc., 78(1-2):13-23.
Omondi, S. and Omondi, J.C. (2015). Phytochemical analysis of fifty (50) selected plants found in the University Botanic Garden, Maseno, Kenya for their chemotaxonomic values. J. Med. Herbs Ethnomed., 1:130-135.

Ozyurt, D.; Ozturk, B.D. and Apak, R. (2004). Determination of total flavonoid content of Urticadioica L. by a new method. Adnan Menderes University. $4^{\text {th }}$ AACD Congress, Turkey, Proceeding's book.

Rajeshwar, Y.; Kumar, G.P.S.; Gupta, M. and Mazumder, U.K. (2005). Studies on in vitro antioxidant activities of methanol extract of Mucuna pruriens (Fabaceae) seeds. European Bull. Drug Res., 13(1):31-39.

Sahu, R. and Saxena, J. (2013). Screening of total phenolic and flavonoid content in conventional and non-conventional species of curcuma. J. pharmacogn. phytochem., 2(1):176-179.

Schulte, S.J.; Baron, R.L.; Teefey, S.A.; Jr Rohrmann, C.A.; Freeny, P.C.; Shuman, W.P. and Foster, M.A. (1990). CT of the extrahepatic bile ducts: wall thickness and contrast enhancement in normal and abnormal ducts. Am. J. Roentgenol., 154(1):79-85.

Sebastian, R.; Jaykar, B. and Gomathi, V. (2020). Current status of anticancer research in Fabaceae family. The Pharma. Innovation Journal, 9(8):52-60.

Shahidi, F.; Janitha, P.K. and Wanasundara, P.D. (1992). Phenolic antioxidants. Crit. Rev. Food Sci. Nutr., 32(1):67-103.

Shakeri, A.; Hazeri, N.; Vizadeh, J.; Ghasemi, A. and Tavallaei, F.Z. (2012). Phytochemical screening, antimicrobial and antioxidant activities of Anabasis aphylla L. extracts. Kragujev. J. Sci., 34:71-78.

Shamsa, F.; Monsef, H.; Ghamooshi, R. and Verdian-rizi, M. (2008). Spectrophotometric determination of total alkaloids in some Iranian medicinal plants. Thai J. Pharm. Sci., 32:17-20.

Srikanth, S. and Chen, Z. (2016). Plant protease inhibitors in therapeuticsfocus on cancer therapy. Front. Pharmacol., 7:470-476.

Tapas, A.R.; Sakarkar, D.M. and Kakde, R.B. (2008). Flavonoids as nutraceuticals: A review. Trop. J. Pharm. Res., 7(3):1089-1099.

Tariq, A.; Sadia, S.; Pan, K.; Ullah, I.; Mussarat, S. and Sun, F. (2017). A systematic review on ethnomedicines of anticancer plants. Phytother Res., 31(2):202-264.

Thakore, P.; Mani, R.K. and Kavitha, S.J. (2012). A brief review of plants having anticancer property. Int. J. Pharm. Res. Develop., 3:129-13.

Tyler, V.D.; Brady, L.R. and Robbers, J.E. (1988). Pharmacognosy (Alkaloids). 9th ed. Lea and Febiger Publisher. Philadelphia, pp:227.

Wink, M. (2013). Evolution of Secondary Metabolites in Legumes (Fabaceae). S. Afr. J. Bot., 89:164-175.

Zheng, F.; Wu, H.; Zhang, R.; Li, S.; He, W.; Wong, F.L.; Zhao, G.L.S. and Lam, H.M. (2016). Molecular phylogeny and dynamic evolution of disease resistance genes in the legume family. BMC Genomics, 17(1):402.

Bhawana Sharma, Raj Shreya, Medha Jha, and Afroz Alam (2021). Prospective of family Fabaceae (Angiosperms) 